\title{
The Effects of Exogenous Rat Growth Hormone Therapy on Growth of Uremic Rats Fed an $8 \%$ Protein Diet
}

\author{
MITSURO NAKANO, GAD KAINER, JOHN W. FOREMAN, DAIJIN KO, AND \\ JAMES C. M. Chan \\ Department of Pediatrics [M.N., G.K., J.W.F., J.C.M.C.], Division of Nephrology, Children's Medical Center, \\ and the Department of Biostatistics [D.K.] Medical College of Virginia, Health Sciences Division of Virginia \\ Commonwealth University, Richmond, Virginia 23298
}

\begin{abstract}
Although the mechanisms underlying the inhibitory effects of chronic renal insufficiency on growth are poorly understood, large doses of growth hormone (GH) have been used to improve growth. The present study examines the effects of rat $\mathrm{GH}$ and a reduced $(8 \%)$ protein diet on $75 \%$ nephrectomized weanling rats by measuring changes in growth parameters, food utilization, serum albumin concentration, and muscle water content. Significantly greater improvement in growth was found in the GH-treated uremic rats compared with the uremic controls. The mean percent change in wt, length (nose to tail tip), and cranial biparietal diameter was significantly increased in the GH-treated uremic rats, compared with the uremic controls, but foot length and femur length showed only moderate improvement. Food utilization efficiency and serum albumin concentration were significantly higher in GH-treated uremic rats compared with uremic controls, achieving levels that were not different from sham-operated rats. Muscle water content was not significantly different between GH-treated uremic rats, uremic controls, and sham-operated rats. Thus, rat GH treatment administered at an early age in mild renal insufficiency significantly improved overall growth, food efficiency, and serum albumin concentrations, despite a low protein diet, suggesting that further evaluation of this form of therapy for growth failure of uremia is warranted. (Pediatr Res 26:204-207, 1989)
\end{abstract}

\section{Abbreviations}

GH, growth hormone

$\mathrm{U}$, uremic control group

$\mathrm{U}+\mathrm{GH}$, uremic rats treated with growth hormone

Growth failure is a major complication of chronic renal insufficiency in children. Adult stature is usually far below that expected for a child's genetic potential, even with adequate dialysis, treatment of acidosis, administration of phosphate binders, nutritional counseling, and supplemental vitamin $\mathrm{D}(1,2)$. Similar findings have been noted in other animal models of chronic renal insufficiency (3-5). Disturbances in the growth hormone/somatomedin system have been implicated in the etiology of the reduced growth rates of children with renal insuffi-

Received February 6, 1989; accepted May 8, 1989.

Correspondence Dr. James C. M. Chan, Medical College of Virginia, $1101 \mathrm{E}$. Marshall St., Richmond, VA 23219. ciency $(6,7)$; however, the mechanisms remain unclear. The recent availability of large quantities of recombinant human growth hormone (8) may open new avenues for the treatment of growth retardation in uremic children. Preliminary data suggest that large doses of recombinant growth hormone can improve growth in uremic children (9).

Large doses of heterologous growth hormone have been used to overcome the inhibitory effect of uremia on growth in fivesixths nephrectomized rats fed $22-24 \%$ protein diets $(10,11)$. With respect to the current concerns regarding the role of high protein intake in the progression of renal damage, the present study was designed to examine the effects of parenteral rat GH in rapidly growing weanling rats with mild chronic renal insufficiency fed a diet containing $8 \%$ protein, $0.8 \%$ DL-methionine, $0.6 \%$ calcium, and $0.6 \%$ phosphorus. The low protein diet was chosen with the aim of increasing survival of the uremic rats by minimizing the damaging effects on the remnant kidney of standard diets containing $22-24 \%$ protein. The effects of GH treatment under this dietary constraint were examined by measuring growth, renal function, food utilization, serum albumin, and muscle water content.

\section{MATERIALS AND METHODS}

The rat GH used in this study was supplied by the National Institute of Diabetes and Digestive and Kidney Diseases, Bethesda, MD (Rat GH-B-10, AFP-8570C). Rat food was purchased from United States Biochemical Corporation, Cleveland, $\mathrm{OH}$, containing $8 \%$ protein, $0.8 \%$ DL-methionine, $0.6 \%$ calcium, and $0.6 \%$ phosphorus. Weanling male Sprague-Dawley rats, 23 $\mathrm{d}$ of age, were purchased from Charles River Laboratory Inc., Raleigh, NC.

Experimental protocol and measurements. The experimental protocol was approved by Virginia Commonwealth University's Institutional Animal Care and Use Committee. The rats were received at $23 \mathrm{~d}$ of age, and at $26 \mathrm{~d}$ of age, they underwent a one-stage right nephrectomy and left heminephrectomy under anesthesia with $50 \mathrm{mg} / \mathrm{kg}$ of pentobarbital. Sham-operated rats $(n=12)$ underwent identical surgical procedure, without nephrectomies, but including decapsulation of both kidneys. After a recovery period of $72 \mathrm{~h}$ during which the experimental diet was supplied, the uremic rats were randomly assigned to a $U$ group $(n=18)$, and a $\mathrm{U}+\mathrm{GH}$ group $(n=10)$. The animals were housed in individual cages with unlimited access to food and deionized water in a controlled room temperature of $22-$ $24^{\circ} \mathrm{C}$ with a light/dark cycle of $12 \mathrm{~h}$. The dose of rat GH remained fixed at $0.5 \mathrm{mg} / \mathrm{d}$ throughout the study. It was prepared daily in $0.15 \mathrm{M} \mathrm{NaCl}$ with $0.05 \mathrm{M}$ sodium bicarbonate adjusted with 0.1 $\mathrm{N} \mathrm{NaOH}$ to a $\mathrm{pH}$ of 9.2 , and was injected subcutaneously at 
$0900 \mathrm{~h}$ for $20 \mathrm{~d}$. The average dose was $7 \mathrm{mg} / \mathrm{kg} / \mathrm{d}$ initially, and as the animals gained wt, the dose at the time of death on the $21 \mathrm{st} \mathrm{d}$ of the study averaged $4 \mathrm{mg} / \mathrm{kg} / \mathrm{d}$. The shams and $\mathrm{U}$ animals received the vehicle only.

All linear measurements were carried out under anesthesia by the same investigator (G.K.) using vernier calipers. Linear parameters measured at 26 and $49 \mathrm{~d}$ of age were nose to tail tip length, foot length, and biparietal diameter. The wt of the rats and the amount of food consumed was determined using an electronic balance every other morning. The 24-h nonfasting urines were collected in Nalgene all-plastic metabolic cages (Sybron Corp., Rochester, NY) on the day before death. At age 49 $\mathrm{d}$, while under anesthesia, the rats were exsanguinated by cardiac puncture. An anterior tibialis muscle was removed and weighed before and after desiccation for $16 \mathrm{~h}$ at $120^{\circ} \mathrm{C}$ to determine muscle water content. Growth data are expressed as percent gain using the following formula: \% gain $=[$ (measurement at death - measurement at nephrectomy)/measurement at nephrectomy] $\times 100$.

Food utilization is expressed as percent food efficiency determined from the wt of the food consumed divided by the wt gained. The average food intake/100 g body wt was calculated by dividing the food consumed by the mean wt of the animal during the experimental period. Urine and serum creatinine concentrations were determined using a Beckman Creatinine Analyzer II (Beckman Instruments, Inc., Brea, CA). Creatinine clearance was determined from the 24 -h urine creatinine and the serum creatinine collected at death. Serum albumin was determined by photometric means using an Albumin Test Kit (Smith Kline Diagnostics, Sunnyvale, CA) with a Serometer model 370 filter photometer.

Femur lengths, nose to tail tip lengths, and wt from 30 additional rats killed at $26 \mathrm{~d}$ of age were used to derive the regression formula: femur length $=0.39+0.0514 \mathrm{NT}+0.0035 \mathrm{WT}(r=$ $0.90, p=0.0001)$. Using this formula, an estimated femur length at the start of the treatment period could be calculated for each rat in the experiment. The femur length at sacrifice minus the estimated length for d 26 was used to calculate the percentage increase in femur length.

Statistical analysis. All data are expressed as the mean \pm SEM. Statistical analysis was performed using Tukey's Studentized range test at $\alpha$ of 0.05 for multiple group comparisons, Student's $t$ test for two group comparisons, and Hotelling's $\mathrm{T}^{2}$ test for vector comparisons on SAS statistical program package, version 5 (SAS Institute, Inc., Cary, NC).

\section{RESULTS}

Effects of $75 \%$ nephrectomy on growth. Reduction of $75 \%$ in renal mass led to a significant fall in creatinine clearance (Table 1). Mean creatinine clearance \pm SEM in the sham group was $0.79 \pm 0.09 \mathrm{~mL} / \mathrm{min} / 100 \mathrm{~g}$ body wt, compared with $0.37 \pm 0.01$ $\mathrm{mL} / \mathrm{min} / 100 \mathrm{~g}$ body wt in the U group, and $0.37 \pm 0.03 \mathrm{~mL} /$ min/100 g body wt in the $U+G H$ group. No significant difference was detected in the creatinine clearance between the $U$ group and the $U+G H$ group (Table 1). In each of the uremic groups, only one rat died during the treatment period, and these two rats were excluded from the study.

Uremic animals treated with the rat $\mathrm{GH}$ had a significantly larger percent mean wt gain of $51.5 \pm 5.0 \%$, compared with 35.8 $\pm 2.8 \%$ in the $U$ group $(p<0.01)$; the percent increase in nose to tail tip length was also significantly increased from $23.0 \pm$ $1.4 \%$ in the $U$ group to $30.3 \pm 2.1 \%$ in the $U+G H$ group $(p<$ $0.01)$. The difference in percent increase in biparietal diameter was also significant at $2.9 \pm 0.5 \%$ in the U group compared with $5.1 \pm 1.1 \%$ in the $\mathrm{U}+\mathrm{GH}$ group $(p<0.05)$. The difference in percent increase in foot length was not as marked: $11.6 \pm 0.6 \%$ in the $U$ group compared with $13.5 \pm 0.8 \%$ in the $U+G H$ group $(p<0.07)$ (Table 2$)$.

The estimated mean \pm SEM of femur length removed from
Table 1. Effects of $G H$ in $75 \%$ nephrectomized rats on food utilization, creatinine clearance, muscle water content, and serum albumin*

\begin{tabular}{lccc}
\hline & $\begin{array}{c}\text { Sham group } \\
(n=12)\end{array}$ & $\begin{array}{c}\text { U group } \\
(n=17)\end{array}$ & $\begin{array}{c}\mathrm{U}+\text { GH group } \\
(n=9)\end{array}$ \\
\hline $\begin{array}{l}\text { Average food intake }(\mathrm{g} / \\
\quad 100 \mathrm{~g} \text { body wt/day) }\end{array}$ & $10.5 \pm 1.0$ & $11: 0 \pm 1.4$ & $11.4 \pm 1.4$ \\
Food efficiency $(\% \mathrm{FE})$ & $23.2 \pm 1.0$ & $18.5 \pm 0.9 \dagger$ & $23.1 \pm 1.7$ \\
Creatinine clearance & $0.79 \pm 0.09 \dagger$ & $0.37 \pm 0.01$ & $0.37 \pm 0.03$
\end{tabular}

$(\mathrm{mL} / \mathrm{min} / 100 \mathrm{~g}$

body wt)

$\begin{array}{llll}\text { Muscle water content } & 75.3 \pm 0.13 & 75.9 \pm 0.18 & 75.1 \pm 0.14\end{array}$

(\% water)

Serum albumin $(\mathrm{g} / \mathrm{dL}) \quad 2.3 \pm 0.1 \quad 1.9 \pm 0.1 \dagger \quad 2.3 \pm 0.1$

$*$ Values are expressed as mean \pm SEM.

$\dagger$ Significantly different from the other two groups at $\alpha 0.05$ using ANOVA and Tukey's Studentized range HSD (honestly significant difference) test. $\mathrm{U}$, uremic control; $\mathrm{U}+\mathrm{GH}$, growth hormone-treated uremic rats; \% FE, percent wt gained/food consumed over treatment period; $n=$ number of animals in each group.

Table 2. Effect of GH treatment on growth in $75 \%$ nephrectomized rats*

\begin{tabular}{lcrrr}
\hline Growth parameter & $\begin{array}{c}\text { Sham group } \\
(n=12)\end{array}$ & $\begin{array}{c}\text { U group } \\
(n=17)\end{array}$ & $\begin{array}{c}\text { U }+ \text { GH group } \\
(n=9)\end{array}$ & $p$ value $\dagger$ \\
\hline Wt & $67.4 \pm 5.1$ & $35.8 \pm 2.8$ & $51.5 \pm 5.0$ & $<0.01$ \\
Nose-tail length & $28.2 \pm 2.6$ & $23.0 \pm 1.4$ & $30.3 \pm 2.1$ & $<0.01$ \\
Biparietal diameter & $5.3 \pm 0.9$ & $2.9 \pm 0.5$ & $5.1 \pm 1.1$ & $<0.05$ \\
Foot length & $14.8 \pm 1.4$ & $11.6 \pm 0.6$ & $13.5 \pm 0.8$ & $<0.07$ \\
Femur length & $31.0 \pm 2.3$ & $27.9 \pm 1.3$ & $30.7 \pm 1.1$ & $<0.17$ \\
\hline
\end{tabular}

* All values are percentage increases, expressed as mean \pm SEM.

$\dagger p$ value obtained using Student's $t$ test between $\mathrm{U}$ and $\mathrm{U}+\mathrm{GH}$ groups. $\mathrm{U}$, uremic control; $\mathrm{U}+\mathrm{GH}$, growth hormone treated uremic rats; $n=$ number of animals in each group.

30 rats at $26 \mathrm{~d}$ of age was $2.11 \pm 0.01 \mathrm{~cm}$. The mean femur length \pm SEM at death was $2.54 \pm 0.02 \mathrm{~cm}$ in the $U$ group and $2.61 \pm 0.04 \mathrm{~cm}$ in the $U+G H$ group. The mean \pm SEM percent increase in femur length at death, determined from the estimated initial femur length, of $\mathrm{U}+\mathrm{GH}$ rats was $30.7 \pm 1.1 \%$, and did not differ significantly from $27.9 \pm 1.3 \%$ in the $\mathrm{U}$ group $(p<$ 0.17 ) (Table 2).

Growth may be defined as an increase in all measurements. Therefore, a comparison of all of the above measurements taken together can be used to assess the overall effects of $\mathrm{GH}$ treatment in rats with renal insufficiency. Such an analysis can be made by expressing the change in each parameter as a vector, making it possible to compare increase in growth between several groups of rats. The $\mathrm{U}+\mathrm{GH}$ rats were significantly larger overall than the $U$ rats, when the combined vectors of percent increase in wt, percent increase in nose to tail tip length, percent increase in foot length, and percent increase in biparietal diameter were compared by Hotelling's $\mathrm{T}^{2}$ test $(p<0.05)$.

Effects of $75 \%$ nephrectomy and $G H$ on food utilization. The mean \pm SEM percent food efficiency of the U group was $18.5 \pm$ $0.9 \%$. This was significantly lower than the $23.2 \pm 1.0 \%$ food efficiency of the sham-operated group, and $23.1 \pm 1.7 \%$ in the $\mathrm{U}+\mathrm{GH}$ a group. The average food intake per $100 \mathrm{~g}$ body wt per day (Table 1) was not significantly different between the sham animals $(10.5 \pm 1.0 \mathrm{~g})$, $U$ animals $(11.0 \pm 1.4 \mathrm{~g})$, and $\mathrm{U}+$ $\mathrm{GH}$ animals $(11.4 \pm 1.4 \mathrm{~g})$.

Serum albumin changes and muscle water content. The serum albumin was significantly less in the $U$ group $(1.9 \pm 0.1 \mathrm{~g} / \mathrm{dL})$ compared with the $\mathrm{U}+\mathrm{GH}$ group $(2.3 \pm 0.1 \mathrm{~g} / \mathrm{dL})$ and sham group $(2.3 \pm 0.1 \mathrm{~g} / \mathrm{dL})$. There was no significant difference in muscle water content between the $\mathrm{U}, \mathrm{U}+\mathrm{GH}$, and sham animals (Table 1). 


\section{DISCUSSION}

Our data suggest that rat GH in large doses, given subcutaneously by daily injections, confers a beneficial effect on various growth parameters in rats with mild renal insufficiency, even under the constraint of a reduced protein diet. The effect on wt gain and vertebral growth appears to be more pronounced than on growth of long bones, because nose to tail tip length increased more than femur length. The percentage increase in foot length, which measures combined cancellous and long bone growth, was not significantly increased in the $\mathrm{U}+\mathrm{GH}$ group compared with the $U$ group, possibly reflecting less effect on metatarsal growth. The biparietal diameter of $U+G H$ group was significantly increased compared to the $\mathrm{U}$ group. It is unclear at the moment whether this finding is secondary to increased brain growth, and additional studies are needed.

We chose the $75 \%$ one-stage nephrectomy rat model, rather than the five-sixths nephrectomy model used by Mehls et al. (10) and Powell et al. (11), which causes severe chronic renal failure, because our study was designed to evaluate the effects of mild renal insufficiency on growth, and thereby to mimic the problems in pediatric patients with moderate renal insufficiency (12). Finally, although survival in the one-stage nephrectomy procedure is more tenuous in weanling rats, we chose this model rather than the two-stage procedure used by others $(10,11)$ to allow the experimental phase to begin at a younger age. The faster growth rate in weanling rats allows a more critical evaluation of the changes in growth variables caused by uremia in combination with $\mathrm{GH}$ therapy.

The $8 \%$ protein diet containing $0.6 \%$ calcium and $0.6 \%$ phosphorus in our protocol was designed to reduce morbidity and improve survival of the uremic animals. Diets with higher protein content used by previous investigators $(10,11)$ worsen uremic symptoms in the rat. These diets also have been shown to be associated with progressive glomerular damage and sclerosis, and with reduced survival $(4,5,13)$. The role of high phosphorus intake in hastening the progression of renal insufficiency is less well defined. However, it appears that a reduction in the dietary phosphorus intake, together with a balanced calcium:phosphorus content can reduce the risk of progression of renal insufficiency (14).

With reference to food utilization, our data revealed a lower food efficiency in the U group. By contrast, in the U+ GH rats, food efficiency increased to the point that it was not different from sham-operated rats (Table 1). There was no difference in food intake between the $U$ group, $U+G H$ group and shamoperated rats in this study. This contrasts with the data of Powell et al. (11), who found that ad libitum-fed sham-operated rats ate significantly more of a high (24\%) protein diet than rats with a five-sixths nephrectomy. This difference may be due to the milder uremia in our rats compared to the rats in the study by Powell et al. (11). Our data also suggest that the improvement in food efficiency, observed in uremic rats treated with growth hormone, is not due to increased appetite and confirm the recent observations of Mehls et al. (10).

The improvement in food efficiency in the $\mathrm{U}+\mathrm{GH}$ group may not necessarily indicate an increase in tissue mass accumulation for each gram of food consumed. Growth hormone can increase fluid retention, and this would lead to increased wt gain and an apparent increase in food efficiency. However, this group had a normal serum albumin concentration, which is inconsistent with marked extracellular fluid retention. Muscle water content, which accounts for a significant proportion of total body water, was the same in all three groups. Therefore, the increase in food efficiency in the uremic rats given growth hormone likely represents a greater increase in tissue accumulation for each gram of food consumed when compared to uremic animals.

The kidneys are the major site of catabolism of growth hormone (15). It is not unexpected, therefore, that in renal insufficiency, serum GH concentrations are normal or high (16-18).
Thus, GH deficiency is not the cause of the reduced growth rates in children with chronic renal insufficiency. Serum somatomedin concentrations in uremia have been reported to be spuriously high or low, depending on the method of analysis. Using radioreceptor or RIA, relatively normal to high somatomedin concentrations were found in children and adults with chronic renal insufficiency $(17-20)$.

Powell et al. (21) have recently demonstrated that a compound, probably unsaturated carrier protein, interferes with the measurement of somatomedins in uremic serum. Removal of this compound by acid-chromatography resulted in normal somatomedin concentrations in uremic adult patients. Using biologic assay methods that measure the incorporation of sulfate into cartilage, decreased somatomedin activity was found in uremic children, which correlated with the reduction in glomerular filtration rate (22). Phillips et al. (23) have shown that acidchromatography of serum before use in a bioassay system led to normal incorporation of sulfate into cartilage, indicating that there must be circulating factors or inhibitors that interfere with the $\mathrm{GH} /$ somatomedin axis in uremia. Our data support continuing efforts to overcome this inhibition by the use of large doses of exogenous growth hormone.

The $75 \%$ nephrectomized weanling rat model allowed us to observe the effects of rat $\mathrm{GH}$ in rapidly growing rodents, before and through puberty. We were able to demonstrate that $\mathrm{GH}$ therapy in mild uremia was growth-enhancing, despite a low protein diet. Further experiments involving larger numbers of animals and over a longer experimental period are still needed to clarify whether GH therapy in renal insufficiency improves the growth of long bones and whether the increased growth rate can be sustained.

Acknowledgments. The authors thank Dr. S. Raiti of the NIDDK, NIH, for the gift of rat GH, Virginia Murrell for secretarial assistance, and Faith Boyle and Martha Wellons for research assistance.

\section{REFERENCES}

1. Rizzoni G, Broyer M, Gest G, Fine R, Holliday MA 1986 Growth retardation in children with chronic renal disease. Scope of the problem. Am J Kidney Dis 4:256-261

2. Hellerstein S, Holliday MA, Grupe WE, Fine RN, Fennell RS, Chesney RW Chan JCM 1987 Nutritional management of children with chronic renal failure. Pediatr Nephrol 1:195-211

3. Wang M, Vyhmeister I, Kopple JD, Swendseid ME 1976 Effect of protein intake on weight gain and plasma amino acid level in uremic rats. Am J Physiol 230:1455-1459

4. Kleinknecht C, Salusky I, Broyer M, Gubler MC 1979 Effect of various protein diets on growth, renal function, and survival of uremic rats. Kidney Int 15:534-541

5. Friedman AL, Pityer R 1986 Beneficial effect of moderate protein restriction on growth, renal function and survival in young rats with chronic renal failure. J Nutr 116:2466-2477

6. Chantler C, Holliday MA 1973 Growth in children with renal disease with particular references to the effects of calorie malnutrition: a review. Clin Nephrol 1:230-242

7. Chesney RW 1987 Growth retardation in childhood renal disease: a hormonal or nutritional problem? Am J Nephrol 7:253-256

8. Kaplan SL, Underwood LE, August GP, Bell JJ, Blethen SL, Blizzard RM, Brown DR, Foley TP, Hintz RL, Hopwood NJ, Johansen A, Kirkland RT, Plotnick LP, Rosenfeld RG, Van Wyk JJ 1986 Clinical studies with recombinant-DNA-derived methionyl human growth hormone in growth hormone deficient children. Lancet 1:697-700

9. Lippe B, Fine RN, Koch VH, Sherman BM 1988 Accelerated growth following treatment of children with chronic renal failure with recombinant growth hormone (Somatrem): a preliminary report. Acta Paediatr Scand [Suppl] 343:127-131

10. Mehls O, Ritz E, Hunziker EB, Eggli P, Heinrich U, Zapf J 1988 Improvement of growth and food utilization by human recombinant growth hormone in uremia. Kidney Int 33:45-52

11. Powell DR, Rosenfeld RG, Hintz RL 1988 Effects of growth hormone therapy and malnutrition on the growth of rats with renal failure. Pediatr Nephrol $2: 425-430$

12. Foreman JW, Chan JCM 1988 Chronic renal failure in infants and children. J Pediatr 113:793-800

13. Hostetter TH, Meyer TW, Rennke HG, Brenner BM 1986 Chronic effects of 
dietary protein in the rat with intact and reduced renal mass. Kidney Int 30:509-517

14. Ibels LS, Alfrey AC, Hant L, Huffer WE 1978 Preservation of function in experimental renal disease by dietary restriction of phosphat. N Engl J Med 298:122-126

15. Johnson V, Maack T 1977 Renal extraction, filtration, absorption, and catabolism of growth hormone. Am J Physiol 233:F185-F196

16. Samaan N, Freeman RM 1970 Growth hormone levels in severe renal failure. Metabolism 19:102-113

17. Lewy JE, Van Wyk JJ 1978 Somatomedin and growth retardation in children with chronic renal insufficiency. Kidney Int 14:361-364

18. Schiffrin A, Guyda H, Robitaille P, Posner B 1978 Increased plasma somatomedin activity in chronic renal failure as determined by acid gel filtration and radioreceptor assay. J Clin Endocrinol Metab 46:511-514
19. Spencer EM, Uthne KO, Arnold WC 1979 Growth impairment with elevated somatomedin levels in children with chronic renal insufficiency. Acta Endocrinol 91:36-48

20. Takano K, Hall K, Kastrup KW, Hizuka N, Shizume K, Kawai K, Akimoto M, Takuma T, Sugino N 1979 Serum somatomedin A in chronic renal failure. J Clin Endocrinol Metabol 48:371-376

21. Powell DR, Rosenfeld RG, Baker DK, Liu F, Hintz RL 1986 Serum somatomedin levels in adults with chronic renal failure: the importance of measuring insulin-like growth factor (IGF-I) and IGF-II in acid chromatographed uremic serum. J Clin Endocrinol Metab 63:1186-1192

22. Schwalbe SL, Betts PR, Rayner PHW, Rudd BT 1977 Somatomedin in growth disorders and chronic renal insufficiency in children. Br Med J 1:679-682

23. Phillips LS, Fusco AC, Unterman TG, DelGreco F 1984 Somatomedin inhibitor in uremia. J Clin Endocrinol Metab 59:764-772 